\title{
Citizenship Education in the Mathematics Curriculum after the Reform of the Education Content in Latvia
}

\author{
Rudīte Andersone $^{1}$ Dr. paed.; Ineta Helmane ${ }^{2}$ Dr. paed. \\ University of Latvia, Latvia \\ rudite.andersone@lu.lv ${ }^{1}$; ineta.helmane@lu.lv²
}

\begin{abstract}
Immense transformations occur in the modern society. Values, human rights, democracy, engagement in the life of the local community, school and the society at large are the content issues to be learnt at school which help to develop into responsible citizens of the country. The issues of citizenship education have been more extensively included both in the teaching/learning content and its implementation in all school subjects, including mathematics. Citizenship education is viewed in three aspects: knowledge about the society, skills to form relations with other people, to establish a safe and supporting environment, to follow rules and norms, attitudes to responsibilities and rights. Mathematics as a school subject is a sphere that has been little researched regarding its content and learning strategies in the aspect of citizenship education. The aim of the study is to explore and assess what changes have taken place after the education content reform in the mathematics curriculum in citizenship education. The data in the qualitative study have been obtained employing documentary research. Three criteria with respective indicators have been chosen for the analysis of the mathematics curriculum: civic knowledge, civic skills, civic values and attitudes. The study analyses two curricula of teaching/learning mathematics that are effective in Latvia for basic school (Grades 1-9) and secondary school (Grades 10-12). The results of the analyses are represented in the comparison showing the data obtained in 2013 and data obtained in 2020. The mathematics curriculum has extensively incorporated skills for learning selfrespect and respect for others, developing the capacity to engage with each other, to contribute to a safe environment, as well as the skills to offer the opportunity to experiment practically with democratic principles, working alone, in small and bigger groups, listening to classmates' opinions and giving arguments for their opinion. The innovation in the new mathematics curriculum is the inclusion of the transversal skills in the learning outcomes, including the civic participation.
\end{abstract}

Keywords: citizenship education, mathematics curriculum, education reform, school education.

\section{Introduction}

Social and economic difficulties, violent extremism and distrust of democratic processes are only some of the threats to the common European principles of justice, democracy, human rights, freedom, equality, tolerance and non-discrimination. Education can increase mutual respect, facilitate fundamental values as well as promote inclusion and equality in this situation. Thus, one of the key themes in education is citizenship education. Its goal is to help pupils to become active, informed and responsible citizens who want and are able to take responsibility about oneself and one's community as well as to participate in the political processes (Citizenship education..., 2017). Citizenship education as an integral part of character education becomes even more important. The promotion of citizenship education at school is one of the goals of European cooperation in education. In 2006, the European Parliament and the Council of the European Union defined among the eight key competences the social and civic competences as vital for people who live in the knowledge-based society (European Parliament..., 2006). The promotion of equality, social cohesion and active citizenship in school education is one of the key goals of this decade envisaged by the Common strategic framework in the field of education and learning system for the cooperation of Europe (Council of the European Union, 2009; Citizenship education..., 2017). Citizenship education is viewed in three aspects. Firstly, it is the knowledge about the society. Secondly, it is skill to form relations with other people, to establish a safe and supporting environment, to follow the rules and norms. Thirdly, it is attitudes to responsibilities and rights (Andersone, Greiškāne, 2011). The European Commission emphasizes the necessity of ensuring that young people acquire social, civic and intercultural competences, by promoting democratic values and fundamental rights, social inclusion and active citizenship, and by enhancing critical thinking and media literacy (European Commission..., 2016; Maass et al., 2019). Citizenship education in the education curricula of most of the European countries incorporates the greatest 
part of competences in connection with democratic and socially responsible action, critical thinking and the interaction of people (Citizenship education..., 2017). Citizenship education helps every pupil to be aware of his/her responsibilities and rights in the society, teaches to evaluate critically phenomena and processes, to express and defend personal opinion (Andersone, Helmane, 2013). If initially citizenship education was more connected with the formation of knowledge-based understanding, then now there is a transition to the formation of active citizenship (Council of the European Union, 2018). The outcome of citizenship education is the active participation of youth in the civil society, which is described by mutual respect and non-violence, which respects human rights and democracy (Hoskins, 2006).

The education curriculum reform is effective in Latvia as of September 1, 2020, and its aim is to help the pupil to develop his/her personality, to engage actively in the societal life, to solve the challenges of everyday life, to acquire skills and motivation to learn life-long and life-wide. This points to the broadening of the importance of citizenship education in the new teaching/learning content in which there is the transfer of emphasis to active application of knowledge and skills in diverse situations. Mathematics as a school subject is a suitable context in citizenship education to promote logical thinking and problem solving as well as self-guided learning. Thus, there emerge preconditions for the formation of habits that are important for the pupil, e.g., "Makes sure whether he/she has understood the question, situation in general and only then starts looking for the solution". The defined learning outcomes in mathematics include such outcomes, the attainment of which requires pupils' cooperation to solve complex problems or research situations that need the generation and discussion of ideas.

\section{Citizenship Education and Mathematics Education}

Citizenship refers to the duties and responsibilities that come with being a member of a community or society. Citizenship values are things people consider to be important in fulfilling these duties and responsibilities, which vary by nation and culture and change over time. They are often political, economic, humanitarian, social, cultural, and behaviour values (Akin, Calik, Engin-Demir, 2017; UNESCO, 2014; Wolbring, 2012; Alghamdi, 2019).

Active citizenship is participation in civil society, community and/or political life, characterized by mutual respect and non-violence and in accordance with human rights and democracy (Missira, 2019; Hoskins, Mascherini, 2009). Active citizenship is the concept of someone who participates in public life (civil society and political life), who takes a role in the community, seeks information and is inspired by the aim of the common good and the respect of human rights (Missira, 2019). Active citizenship is strongly related to civic engagement and plays a crucial role in building social capital as connections between individuals - social networks and the norms of reciprocity and trustworthiness that arise from them (Putnam, 2000; Putnam, 2002; Missira, 2019). Active citizenship holds that citizenship is not solely comprised of passive membership of a political entity, but that being active is essential of being a citizen. It is about being willing to contribute to social action as well as to political debate, to be willing to get involved (Brannan, John, Stoker, 2006; Missira, 2019). Civic participation can be understood as a right, need or even an obligation; its meaning narrowed to participation in elections, or extended to various areas of political, social and civil life; or processed in functional or political terms, including a critical evaluation of social problems and the pursuit of systemic change (Hoskins, Saisana, Villalba, 2015; Westheimer, Kahne, 2004; de Groot, Veugelers, 2015; Hoskins, Kerr, 2012; Kopińska, 2020).

Citizenship education is not only the transfer of societal values and attitudes but also their transformation, changing them according to political and ideological aims (Sandström, Stier, 2008). Civic education does not mean the preparation for civic participation, it is actually the education for civic participation, and thus it should incorporate the education for citizenship. Citizenship education should help pupils develop knowledge and skills, competences and values which enable active and responsible participation (Karakatsani, 2008; Missira, 2019).

STEM knowledge is fundamental for being an actively engaged and responsible citizen and for becoming fully aware of the complex challenges that our society faces. It helps to explain and understand the world, to guide technological development and innovation and to plan for the future (European Commission, 2015; Maass et al., 2019). Science (including mathematics) education has focused on the 'learning of science' (European Commission, 2015), with pure science detached from societal implications. This focus can be contrasted with learning 'of and about science' (Osborne, Dillon, 2008; Maass et al., 2019). 
It is often neglected that science has social, cultural and ethical dimensions. Learning of and about science also fosters young people's understanding of nature of applications and implications of science. Consequently, by learning of and about science, they learn principles and competences vital in democratic, pluralistic and increasingly multi-cultural European societies. In this sense, science and mathematics education also have become part of citizenship education (Maass et al., 2019).

Throughout human history mathematics plays a key role in intellectual and professional development and is considered an integral part of human culture, because of creating an understanding of the surrounding world, providing a scientific basis and ensuring the development of technology. Mathematical studies have a decisive role in education, forming systematic thinking, forming the person's cognitive abilities, as well as logical thinking and influencing the teaching process of other disciplines (Yusupova, Ibyatova, 2018; Vintere, Cernajeva, 2019). School mathematics is not the same as academic mathematics; it is rather one of the many interfaces between mathematics and society to see the obstacles and opportunities for one dimension of social turn in school mathematics (Popkewitz, 2004). Mathematics education in the third millennium will not just be about teaching and learning mathematics, but about the nature of knowledge and the place of mathematics in society. One of the central aims of the school curriculum should be a concern to understand the place, purpose and power of mathematics in the society. It is important for mathematics educators to appreciate the role of (school) mathematics so that learners can come to appreciate how mathematics works in society. If such a shift is to translate into actual educational practice in schools, it seems clear that certain political, sociocultural and curricular conditions need to be in place (Noyes, 2007; Falkenberg, Noyes, 2010).

The aim of the study is to explore and assess what changes have occurred after the education content reform in the mathematics curriculum in citizenship education.

\section{Methodology}

The question of the present research: what is the content of citizenship education (knowledge, skills, and attitudes) in mathematics curriculum? The present study has explored and assessed what changes have occurred after the education content reform in Latvia in the mathematics curriculum in citizenship education. The data in the qualitative study have been obtained employing such a research method as documentary research. Three criteria with respective indicators have been chosen for the analysis of the mathematics curriculum: civic knowledge, civic skills, civic values and attitudes (Andersone, Helmane, 2012). The study analyses two curricula of teaching/learning mathematics that are effective in Latvia for basic school (Grades 1 - 9) and secondary school (Grades 10 - 12): Mathematics curriculum Grades 1 - 9 (Matemātika 1.-9. klasei, 2019), Mathematics I curriculum of the basic course for the general secondary education (Matemātika I..., 2019), Mathematics Grades 1 - 9 (Matemātika 1.-9. klasei, 2005), Mathematics Grades 10 - 12 (Matemātika 10.-12. klasei, 2008).

The mathematics curriculum (Matemātika 1.-9. klasei, 2005; Matemātika 10.-12. klasei, 2008) mainly described the expected outcomes in the content aspect of teaching/learning mathematics, without paying attention to value education, citizenship education and the issues related to character education. In turn, the new teaching/learning content in mathematics is organized according to the most essential key concepts of the content that the pupil has to acquire to develop common understanding about the surrounding world and oneself in it. The key concepts of are the form the structural framework of the compulsory teaching/learning content; requirements for the acquisition of the teaching/learning content or the learning outcomes that the pupil has to attain finishing the particular stage of education are described according to content. These learning or expected outcomes are defined both for each theme in the teaching/learning content and the respective educational three-year stage, finishing Grades 3,6 and 9. The learning outcomes at the end of the respective educational stage define also the learning outcomes in connection with the acquisition of transversal skills, including the civic participation which directly refers to citizenship education. This is a new formation in the mathematics curriculum which has been developed as a result of the education content reform. Besides, the basic course mathematics curriculum of the secondary school was used in the analysis of the mathematics content for Grades $10-12$ where the content is no longer divided per particular grades, but the general common content for all secondary school grades is given together. This allows schools to organize themselves the acquisition of the content in the particular sequencing during this period. This is the novelty after the introduction of the education content reform. This also defines the transversal skills, such 
as critical thinking and problem solving, innovation and entrepreneurship, self-guided learning, cooperation, civic participation and digital literacy (Matemātika 1.-9. klasei, 2019; Matemātika I..., 2019). This study analyses the learning outcomes in the new mathematics curriculum according to the selected criteria at the end of the education content stages (finishing Grades 3, 6, 9 and 12).

\section{Results and Discussion}

The results of the analyses are represented in the comparison showing the data obtained in 2013 (Andersone, Helmane, 2013) and data obtained in 2020. Thus, it is before the education content reform and after it pointing to the significant changes in citizenship education that have occurred based on the education content reform (Table 1).

Table 1

Citizenship education criteria and indicators for mathematics curriculum

\begin{tabular}{|c|c|c|c|c|c|c|c|c|c|c|c|c|c|c|}
\hline \multirow{2}{*}{ Criteria } & \multirow{2}{*}{ Indicators } & \multirow{2}{*}{ Year } & \multicolumn{12}{|c|}{ Mathematics curriculum for each grade } \\
\hline & & & 1. & 2. & 3. & 4. & 5. & 6. & 7. & 8. & 9. & 10. & 11. & 12. \\
\hline \multirow{6}{*}{ 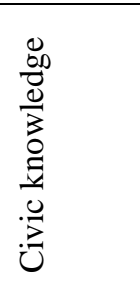 } & \multirow{2}{*}{$\begin{array}{c}\text { Theory of human rights } \\
\text { and democracy }\end{array}$} & 2013 & & & & & & & & & & & & \\
\hline & & 2020 & & & & & & & & & & & & \\
\hline & \multirow{2}{*}{$\begin{array}{c}\text { Theory of human rights } \\
\text { and democracy }\end{array}$} & 2013 & & & & & & & & & & & & \\
\hline & & 2020 & & & & & & & & & & & & \\
\hline & \multirow{2}{*}{$\begin{array}{l}\text { Cultural and historical } \\
\text { diversity }\end{array}$} & 2013 & & & & & & & & & & & & \\
\hline & & 2020 & & & & & & & & & & & & \\
\hline \multirow{6}{*}{$\begin{array}{l}0 \\
\frac{0}{n} \\
.0 \\
0 \\
0\end{array}$} & \multirow{2}{*}{$\begin{array}{c}\text { Involvement in the life } \\
\text { of the school, local } \\
\text { community }\end{array}$} & 2013 & & & & & & & & & & & & \\
\hline & & 2020 & & & & & & & & & & & & \\
\hline & \multirow{2}{*}{$\begin{array}{l}\text { Contribution to safe } \\
\text { environment }\end{array}$} & 2013 & & & & & & & & & & & & \\
\hline & & 2020 & & & & & & & & & & & & \\
\hline & \multirow{2}{*}{$\begin{array}{c}\text { Experiment practically } \\
\text { with democratic } \\
\text { principles }\end{array}$} & 2013 & & & & & & & & & & & & \\
\hline & & 2020 & & & & & & & & & & & & \\
\hline \multirow{6}{*}{ 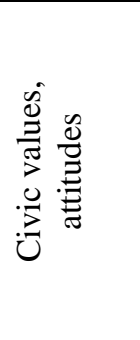 } & \multirow{2}{*}{$\begin{array}{l}\text { Developing values } \\
\text { consistent with a } \\
\text { pluralist society }\end{array}$} & 2013 & & & & & & & & & & & & \\
\hline & & 2020 & & & & & & & & & & & & \\
\hline & \multirow{2}{*}{$\begin{array}{l}\text { Learning self-respect } \\
\text { and respect for others }\end{array}$} & 2013 & & & & & & & & & & & & \\
\hline & & 2020 & & & & & & & & & & & & \\
\hline & \multirow{2}{*}{$\begin{array}{l}\text { Developing capacity to } \\
\text { engage with each other }\end{array}$} & 2013 & & & & & & & & & & & & \\
\hline & & 2020 & & & & & & & & & & & & \\
\hline
\end{tabular}

The studying of the mathematics curriculum allows concluding that there have been significant changes resulting from the education content reform in favour of including citizenship education in learning mathematics. The reform reflects the society's needs for bringing up active members, conscientious citizens of the society. The innovation in the new mathematics curriculum is the inclusion of transversal skills in the learning outcomes, including civic participation. Civic participation as a transversal skill envisages that the learner develops an active life position and consolidates the personal conviction about each individual's potentiality to affect and change the environment and the current situation; he connects the sustainability of the society and environment with the individual's everyday actions and recognizes it on both the local and global scale; he explores empathetically the diverse opinions, acts in the spirit of solidarity and responsibly, in discussions searches for solutions to the contradictory situations and together with others implements these solutions (Skola2030, 2019).

Civic knowledge is mainly targeted towards transferring information and knowledge about the country's geography and history, the underlying principles of its constitution, the main organizational models and political system. Pupils' passive (essentially passive) understanding about the theory of human rights and 
democracy, cultural and historical diversity can be learned in all stages of mathematics education. According to the information found in the mathematics curriculum, when learning mathematics pupils can acquire and get to know social, civic and political institutions, human rights, cultural and historical heritage as well as cultural and linguistic diversity of society (Matemātika I..., 2019; Matemātika 1.-9. klasei, 2005). For instance, in Grade 1 pupils use a monthly calendar in which they look for and name the date or days of the week for a particular event that is significant for the community in a narrower or broader context; finishing Grade 3 pupils notice that different people have different opinions, they name their values. Before the reform, it was included only in the curriculum of separate grades. Yet, the multicultural environment is a modern reality in which pupils function every day, including mathematics lessons (Skola2030, 2019; Matemātika 1.-9. klasei, 2005). Finishing Grade 6, pupils identify regularities in the society, environment and community on a national scale as well as their impact, role and necessity to engage in the improvement of their community life applying the knowledge and skills acquired in mathematics. They are able to explain the different consequences of one action (their impact on other people, relations, and environment). The previous mathematics curriculum had a narrower perspective, according to that pupils were able to see the connections between the variables in nature, society, technical equipment and to solve practical tasks that were connected with everyday life, science, environment and health issues, were aware of their importance in everyday life. In turn, finishing Grade 9, pupils explain their views on the regularities in the society, environment, and community on the European scale and substantiate it based on the information and statistical data found in different resources. They analyse how the action of separate individuals affects the society and environment applying mathematical coherence and mathematical language. In the previous curriculum, pupils had to understand the applicability of the variability term in the analysis of everyday processes and be able to provide precise arguments for the opinion that was connected only with one aspect of citizenship education, namely, the ability to explain one's ideas. After the mathematics content reform, finishing Grade 12, pupils explain and give arguments for their opinions about the interconnections both on the local scale and globally, evaluate the individual and the interaction of the society and the environment, while the old mathematics curriculum envisaged only that pupils were able to apply the mathematics knowledge and skills in their everyday life and professional activities saying nothing about the citizenship education (Skola2030, 2019; Matemātika 10.-12. klasei, 2008).

Civic skills contribute to a safe environment and the opportunity to experiment practically with democratic principles are included in the curricula of all stages of education as before. The innovation is the inclusion of skills of being involved in the life of the school and local community in the mathematics curriculum already starting with Grade 1. Finishing Grade 3, pupils engage in the improvement of the school life with the teacher's support and determine what has changed afterwards. Finishing Grade 12, in turn, pupils independently and together with others gain experience engaging in searching for and implementing solutions that help to improve the quality of life. Therefore, also in learning mathematics it is possible to cultivate pupils' conviction to observe the civic behaviour working in the class or outside it, creating the possibility for them in learning mathematics to take different initiatives. For example, it is advisable in Grade 1 to organize pupils' cooperation in pairs, in small groups performing actions, tasks necessary for acquiring the theme. Thus, it is possible to form the understanding if the pupil alone has no ideas, conviction; it is possible to compare the results, to discuss the ways of solution. Pupils themselves can make tasks and exchange them. In Grade 3 pupils design models of real and imagined buildings; they depict visually, explain and substantiate their thoughts and solution developing the habit of seeking the solution in new situations.

Civic values, attitudes are necessary so that pupils have more possibilities to engage in the diverse actions of the society as well as in the formation of opinions and attitudes, thus becoming informed and responsible citizens. Civic values and attitudes, learning self-respect and respect for others and developing the capacity to engage with each other have stayed unchanged in the mathematics curriculum also after the reform in all stages of education. However, after the reform, special attention is paid to developing values consistent with a pluralist society that until now had not been included in the mathematics curriculum. For instance, finishing Grade 6 pupils seek the substantiation of actions and opinions of others, name and justify personal values and those of his/her family members and school, acts in accordance with the personal values. Finishing Grade 9, in turn, pupils draw conclusions based on their experience as well analysing different sources on how values can change in the course of time. Based on personal values, they choose events in which to engage and if necessary to involve others, explain and give arguments for their choice or reasons 
for not engaging. They guide their actions in conformity with their values and justify their choices. And finishing Grade 12, based on their values and respecting the values of others, they choose advisedly the events and everyday situations in which to engage and involve others, justifying their position respectfully, they know how to express themselves, how to refuse if the event fails to comply with the values and are able not to yield to the group pressure, staying connected with those with whom they disagree. The mathematics curriculum contains references to social and moral responsibility, including self-confidence, and learning to behave responsibly towards others, contribute to a safe environment; recognition of and respect for oneself and others with a view to achieving greater mutual understanding; the construction of values for respecting social perspectives and points of view. For example, in Grade 1 pupils express their thoughts about why it is necessary to measure length, distance and name everyday situations in which measuring is applied; they explain their answers, thought, idea developing the habit to think over the solution (it helps the pupil both to guide his own learning and to cooperate successfully with others); in Grade 3 solving the situation tasks as well as making the situation descriptions according to numerical expressions, they develop the habit of applying the acquired in concrete, including unknown, life situations, and in Grade 12 they independently and together with others gain experience engaging in seeking the solutions and implementing them which helps to improve the life quality applying the knowledge and skills learnt in mathematics.

\section{Conclusions}

The new mathematics curriculum incorporates the planning of the mathematics teaching/learning content and learning outcomes. The innovation in the new mathematics curriculum is defining transversal skills, including civic participation, as the pupils' learning outcome. Civic participation is an integral part of citizenship education that is necessary for every member of the society implementing the citizen's rights and responsibilities and demonstrating a civic stand, which is developed also in mathematics lessons.

Taking into consideration the specifics of the school subject, the mathematics curriculum has extensively incorporated skills for learning self-respect and respect for others, developing the capacity to engage with each other, to contribute to a safe environment, as well as the skills to offer the opportunity to experiment practically with democratic principles, working alone, in small and bigger groups, listening to classmates' opinions and giving arguments for their opinion.

The innovation in the mathematics curriculum in citizenship education is the inclusion of skills of developing values consistent with a pluralist society in the learning outcomes. Before the reform, no attention was paid to that in mathematics studies. Today's world changes rapidly and the understanding of values is significant in the life of the society as well as the understanding of the diversity of cultures because the multicultural environment is part of the globalized world. The mathematics curriculum envisages its development throughout the schooling starting from Grade 1. For instance, pupils participate in mathematics lessons in homogeneous and heterogeneous group works, accept differences in opinions, participants' diverse experience and abilities, they predict, eliminate and solve disagreements and conflicts, also in the digital environment.

In general, it can be concluded that due to the education content reform the mathematics curriculum incorporates citizenship education to a greater extent and it can be implemented both in the teaching/learning content and in learning and it is one of the pupils' learning outcomes.

\section{Bibliography}

1. Akin S., Calik B., Engin-Demir C. (2017). Students as change agents in the community: Developing active citizenship at schools. Educational Sciences: Theory and Practice, 17(3), 809-834. doi: 10.12738/estp.2017.3.0176

2. Alghamdi K.H.A. (2019). Citizenship Education in Science Curricula: Exploring the Saudi Arabia Case. International Journal of Science and Mathematics Education, 18, 669-689. doi: 10.1007/s10763-019-09991-2

3. Andersone R., Greiškāne A. (2011). Pilsoniskā izglìtība mācību programmās [Citizenship education in curricula]. In Pedagoǵija: teorija un prakse VI Izglītîba un pilsoniskā sabiedrība. Liepāja: LiePA, 37-44. (in Latvian) 
4. Andersone R., Helmane I. (2012). Mathematics Textbook for Citizenship Education. In V. Dislere (Ed.), The Proceedings of the International Scientific Conference Rural Environment. Education. Personality (REEP), 5. Jelgava: LLU, 88-95. Retrieved from https://lufb.llu.lv/conference/REEP/2012/REEP-2012-proceedings-E-ISSN-2255-808X.pdf\#page=89

5. Andersone R., Helmane I. (2013). Citizenship Education in the Mathematics Curriculum. In V. Dislere (Ed.), The Proceedings of the International Scientific Conference Rural Environment. Education. Personality (REEP), 6. Jelgava: LLU, 173-179. Retrieved from https://llufb.llu.lv/conference/REEP/2013/Latvia-Univ-Agricult_REEP_2013_ISSN_2255808X-173-178.pdf

6. Brannan T., John P., Stoker G. (2006). Active Citizenship and Effective Public Services and Programmes: How Can We Know What Really Works. Urban Studies, 43(5/6), 993-1008. doi: 10.1080/00420980600676626

7. Citizenship education at school in Europe - 2017. Eurydice Report. (2017). European Commission/EACEA/Eurydice. Luxembourg: Publications Office of the European Union. doi: $10.2797 / 536166$

8. Council of the European Union. (2009). Council conclusions of 12 May 2009 on a strategic framework for European cooperation in education and training (ET 2020), OJ C 119, 28.5.2009, 2-10. Retrieved from https://eur-lex.europa.eu/legal-content/EN/ALL/?uri=celex:52009XG0528(01)

9. Council of the European Union. (2018). Council Recommendation of 22 May 2018 on key competences for lifelong learning (2018/C 189/01); ST/9009/2018/INIT; OJ C 189, 4.6.2018, 1-13. Retrieved from https://eur-lex.europa.eu/legal-content/EN/TXT/?uri=uriserv:OJ.C_.2018.189.01.0001.01.ENG

10. de Groot I., Veugelers W. (2015). Why We Need to Question the Democratic Engagement of Adolescents in Europe. Journal of Social Science Education, 14(4), 27-38. doi: 10.4119/UNIBI/jsse-v14-i4-1426

11. European Commission. (2015). Science education for responsible citizenship. doi: 10.2777/12626

12. European Commission/EACEA/Eurydice. (2016). Promoting citizenship and the common values of freedom, tolerance and non-discrimination through education: Overview of education policy developments in Europe following the Paris Declaration of 17 March 2015. Luxembourg: Publications Office of the European Union. doi: 10.2797/396908

13. European Parliament, Council of the European Union. (2006). Recommendation of the European Parliament and of the Council of 18 December 2006 on key competences for lifelong learning (2006/962/EC); OJ L 394, 30.12.2006, 10-18 Retrieved from https://eurlex.europa.eu/eli/reco/2006/962/oj

14. Falkenberg T., Noyes A. (2010). Conditions for linking school mathematics and moral education: A case study. Teaching and Teacher Education, 26(4), 949-956. doi: 10.1016/j.tate.2009.10.036

15. Hoskins B. (2006). Draft Framework on Indicators for Active Citizenship. Ispra: CRELL Retrieved from

https://citeseerx.ist.psu.edu/viewdoc/download?doi=10.1.1.132.1723\&rep=rep1\&type=pdf

16. Hoskins B., Kerr D. (2012). Final Study Summary and Policy Recommendations Report: Participatory citizenship in the European Union. Institute of Education report for EU. Southampton: University of Southampton. Retrieved from

https://ec.europa.eu/citizenship/pdf/report_4_final_study_summary_and_policy_recommendations_.pdf

17. Hoskins B., Mascherini M. (2009). Measuring Active Citizenship through the Development of a Composite Indicator. Journal of Social Indicator Research, 90(3), 459-488. doi: 10.1007/s11205-008-9271-2

18. Hoskins B., Saisana M., Villalba C.M.H. (2015). Civic Competence of Youth in Europe: Measuring Cross National Variation through the Creation of a Composite Indicator. Social Indicators Research, 123(2), 431- 457. doi: 10.1007/s11205-014-0746-z

19. Karakatsani D. (2008). The role of education in the context of Social and Civic Education. Professionalism, self-development and teaching strategies. In S. Balias (Ed.), Active citizen education. Athens: Papazisis, 151-173.

20. Kopińska V. (2020). Student participation in the discourse of Polish Citizenship Education textbooks for upper secondary school. Journal of Social Science Education, 19(1), 172-187. doi: $10.4119 /$ jsse-1522 
21. Maass K., Doorman M., Jonker V., Wijers M. (2019). Promoting active citizenship in mathematics teaching. ZDM Mathematics Education, 51, 991-1003. doi: 10.1007/s11858-01901048-6

22. Matemātika 1.-9. klasei [Mathematics 1-9 grade]. (2005). Valsts izglītības satura centrs. Retrieved from https://www.visc.gov.lv/sites/visc/files/data_content/matematika_1_9.pdf (in Latvian)

23. Matemātika 1.-9. klasei. Mācību priekšmeta programmas paraugs [Mathematics 1-9 grade. Mathematics curricula]. (2019). Valsts izglìtîbas satura centrs, Skola2030. Retrieved from https://mape.skola2030.1v/resources/159 (in Latvian)

24. Matemātika 10.-12. klasei [Mathematics 10-12 grade]. (2008). Valsts izglīîibas satura centrs. Retrieved from https://www.visc.gov.lv/sites/visc/files/mat_prog_proj1.pdf (in Latvian)

25. Matemātika I. Pamatkursa programmas paraugs vispārējai vidējai izglīīībai [Mathematics I. Mathematics curricula]. (2019). Valsts izglìtibas satura centrs, Skola2030. Retrieved from https://mape.skola2030.1v/resources/351 (in Latvian)

26. Missira V. (2019). Strengthening European citizenship education. Journal of Social Science Education, 18(3), 55-68. doi: 10.4119/jsse-1456

27. Noyes A. (2007). Rethinking school mathematics. London: Paul Chapman.

28. Osborne J., Dillon J. (2008). Science education in Europe: Critical reflections: A report to the Nuffield Foundation. London, UK: Nuffield Foundation. Retrieved from https://mk0nuffieldfounpg9ee.kinstacdn.com/wpcontent/uploads/2019/12/Sci_Ed_in_Europe_Report_Final1.pdf

29. Popkewitz T. (2004). School subjects, the politics of knowledge, and the projects of intellectuals in change. In P. Valero, R. Zevenbergen (Eds.), Researching the socio-political dimensions of mathematics education. Mathematics Education Library, 35. Boston, MA: Springer, 251-268. doi: 10.1007/1-4020-7914-1_20

30. Putnam R.D. (2000). Bowling Alone: The collapse and revival of American community. New York: Simon, Schuster.

31. Putnam R.D. (2002). Democracies in Flux: The Evolution of Social Capital in Contemporary Society. New York: Oxford University Press. doi: 10.1093/0195150899.001.0001

32. Sandström M.K., Stier J. (2008). Citizenship in the classroom: transferring and transforming transcultural values. Intercultural Education, 19(1), 41-51. doi: 10.1080/14675980701852384

33. Skola2030 [School 2030]. (2019). Valsts izglìtības satura centrs. Retrieved from https://www.skola2030.lv/lv (in Latvian)

34. UNESCO. (2014). Global citizenship education. Preparing learners for the challenges of the 21st century. Retrieved from https://www.unesco.at/fileadmin/Redaktion/Publikationen/PublikationsDokumente/2014_UNESCO_GCED_Preparing_learners.pdf

35. Vintere A., Cernajeva S. (2019). A Case of Competence Building - International Student Scientific Mathematics Olympiad. In V. Dislere (Ed.), The Proceedings of the International Scientific Conference Rural Environment. Education. Personality, 12. Jelgava: Latvia University of Life Sciences and Technologies, 196-202. doi: 10.22616/REEP.2019.025

36. Westheimer J., Kahne J. (2004). What Kind of Citizen? The Politics of Educating for Democracy. American Educational Research Journal, 41(2), 237-269. doi: 10.3102/00028312041002237

37. Wolbring G. (2012). Citizenship education through an ability expectation and "ableism" lens: The challenge of science and technology and disabled people. Education Sciences, 2, 150-164. doi: $10.3390 /$ educsci2030150

38. Yusupova O., Ibyatova L. (2018). New approaches in mathematics education: the regional development concept of mathematics education. In V. Lubkina (Ed.), The Proceedings of the International Scientific Conference Society. Integration. Education, 1, 590-599. Retrieved from http://journals.ru.lv/index.php/SIE/article/download/3230/2989 